\title{
Review
}

\section{DIABULIMIA - CULTURAL DETERMINANTS OF EATING DISORDERS}

\author{
B. Hoffmann* \\ Institute of Applied Social Sciences, University of Warsaw, Poland
}

\begin{abstract}
Eating disorders are becoming an increasingly common problem. This problem becomes particularly dangerous when it concerns specific groups in which the occurrence of any nutritional irregularities constitutes a serious threat to health and even life. This is the case for diabulimia, which I will present in more detail in this article. Personality predispositions and socio-cultural factors are determined as the main risk factors of development of eating disorders, inclusive diabulimia.
\end{abstract}

Key words: diabulimia, eating disorders, insulin-dependent diabetes, risk factor, appearance, addiction, consumer culture.

Eating disorders are becoming an increasingly common problem that involves more and more social groups. The most frequently described disorders include anorexia and bulimia; however the problem goes beyond these entities of disease. Although atypical forms of eating disorders do not meet all diagnostic criteria, they constitute a significant individual and social problem. This problem becomes particularly dangerous when it concerns specific groups in which the occurrence of any nutritional irregularities constitutes a serious threat to health and even life. This is the case for diabulimia, which I will present in more detail in this article.

\section{EATING DISORDERS - SHORT CHARACTERISTICS}

Although many times you may find the opinion that eating disorders are closely related to contemporary cultural processes, models and aesthetic ideals (1), traces of existing nutrition problems have also been found in the past, even though in former times they were not perceived as disorders.

\footnotetext{
*Correspondence to: Dr hab. Beata Hoffmann, Institute of Applied Social Sciences, University of Warsaw, Poland, hoffmann.beata@gmail.com
}

And so, already from the records of Hippocrates, you could learn about the morbid abstention from eating, in relation to which the terms: asitia and inedia were used. In turn, Galen drew attention to this disorder, referring it to his concept of humoral fluids conditioning the state of the organism. According to Galen, gastrointestinal dysfunction was supposed to be the cause of anorexia nervosa. In the following centuries, the perception of abstaining from eating has changed. In the Middle Ages, people refusing food were treated as exceptional, often holy, living thanks to religious zeal and strong faith (2). As a result of the ongoing cultural changes of the Renaissance, there has been a departure from the interpretation of hunger strikes through the prism of religion. This was to some extent resumed during the Baroque period. Then the refusal to accept food was part of the rituals associated with mourning, and was seen as the way to achieve a union with Christ (3). Thanks to the development of medicine and natural sciences in the Enlightenment, there has been significant progress in the "diagnosis" of anorexia nervosa. In 1840 the study of the French physician Fleury Imbert and his work entitled Traité théorique et pratique des maladies des femmes, not only distinguished 
gastric anorexia (anorexia gastrique) and nerve anorexia (anorexia nerveuse), but also drew attention to the fact that this problem concerned women. A decade later, in 1860, Louis - Victor Marce published an article, which showed that it is certainly not the digestive tract that is responsible for anorexia but a certain type of delirium (4).

Subsequently, the "new disorder" became the subject of independent research by the doctors: the Englishman, Sir William Wishey Gull and the Frenchman Ernest Charles Laseque. First, in 1868, the term Apepsia histeria was used to describe anorexia, then it was soon replaced with the term "Anorexia". The characteristic of a new disease entity has been translated into several languages and appeared in professional American, German, Italian and Dutch literature (5). Since then, anorexia began to be treated as a mental illness, the effects of which are also felt by the physical side of a human body.

At the beginning of the twentieth century, a French neurologist and one of the founders of the psychiatry - Jean-Martin Charcot and his student - Pierre Janet and Siegmund Freud drew attention to the importance of both psychological factors, and the family environment in the development of anorexia. There were also views that emphasized the organic basis of this disease. The German doctor, a pathologist - Morris Simmonds became an advocate of such view (6). This view will divert attention from the psychological conditions of anorexia (7) for many years to come.

In the 1960s of twentieth century, due to the development of psychology and humanistic psychiatry, the search for psychological foundations for the development of anorexia returned. In the following decades, there was an increased interest in this disorder, and most importantly, the attitude of doctors and therapists to anorexia nervosa has changed.

Among the theories attempting to explain the causes of eating disorders, psychological, biological and social concepts gained popularity. As the research progressed, subcategories of anorexia were distinguished. A special place was taken by bulimia, distinguished and described in 1979 by the English doctor - Gerald Russell (8).

In 1997, the doctor Steven Bratman used the term "Orthorexia nervosa" for the first time, where ortho means "correct", and orexis -
HOFFMANN B.

"appetite" (9). Interestingly, this entity of eating disorder was not only the subject of his professional practice, but his own experience. Even as a child, Bratman was forced to eliminate wheat and dairy products from his menu. Gradually, the fear of eating products that could harm him caused a strong control of everything he consumed. In the following years, the concern about the only diet that is right in his opinion, as well as a way of preparing and consuming dishes, took a form of obsession. The so-called healthy diet has become the sole purpose of his life. Many hours of daily involvement in preparing meals getting familiar with the literature on healthy eating, health-food stores, and collecting new, more and more restrictive diets, led to restrictive dietary limitations. Concentration on the diet became the only activity of Bratman and the only goal he aspired to.

Initially, he avoided friends and acquaintances to finally isolate himself completely, committing himself to the only correct, in his opinion, occupation - preparing the right meals. Graduation of medical studies and taking up a job, contributed to Bratman's change of perception of his own person. Meeting in his office patients who rigorously adhered to diets, he noticed an analogy between their behavior and his own one. This prompted him to classify this problem as a health disorder.

Diabulimia is definitely a less known eating disorder than anorexia, bulimia or orthorexia. The term "diabulimia" arose from the combination of two words: diabetes and bulimia (one of the eating disorders). Although in the popular press, the term "diabulimia" appeared in 2007 (10), the problem of this type of disorder was already described in the 1970s and 1980s (11), in current medical classifications, including such as DSM- IV and ICD-10, diabulimia does not occur. It does not change the fact that it is a dangerous phenomenon, leading to very serious health consequences, and even to death (12). In addition, it is worth emphasizing that diabulimia affects young people who are often in the phase of their adolescence. Because this form of eating disorder refers to a specific group in which the occurrence of any nutritional irregularities becomes particularly dangerous, it requires both publicity as well as appropriate preventive actions. 


\section{DEFINITION CRITERIA}

According to the definition of the National Eating Disorders Association, diabulimia is an eating disorder that involves deliberately omitting insulin doses to reduce body weight or prevent gain of weight in people with type 1 diabetes (13). These patients give themselves less insulin than their body needs, which becomes dangerous for health and even life.

At this point the question arises, what is the "mechanism" of weight loss in this case? If the body lacks insulin, it is not able to draw energy from the carbohydrates it was provided. Carbohydrates, that are sugars, are a kind of fuel for muscles and brain. According to the recommendations of dieticians, they should be the basis for the menu. The problem is that the mere supply of carbohydrates to the body and digesting them does not feed us yet. That is the insulin which is needed so that the energy obtained from carbohydrates, strengthen the cells of our body. If we do not have it, the energy is excreted together with the urine, which results in large amounts of sugar in the urine of type 1 diabetes. But the body is unable to function without any fuel in the long run, so in the absence of insulin, it switches to use fat. And not only this supplied with food, but also that stored for a rainy hour, in the form of adipose tissue. Therefore, people who do not have their own insulin and do not provide it from the outside, regardless of how much they eat, and so lose kilograms. The mechanism of this weight loss is double - the energy cannot be used, and in addition, the body reaches for fat, because it must be somehow nourished. As a result of burning fat in blood, ketone bodies appear, which constitute an alternative source of energy for the brain and heart, but are not the source of energy for the cells of muscles, for example. Thus, in the absence of insulin, we are able to survive for some time - because the brain gets substitute fuel, but the insulindependent cells (the majority in a human body) are undernourished (14).

\section{DIABETES MELLITUS TYPE 1 (INSULIN-DEPENDENT DIABETES)}

The underlying cause of type 1 diabetes is a chronic autoimmune disease process leading to the slow destruction of insulin producing beta cells, as a result of which the body is not being able to produce insulin itself (15). The disease is treated by administering throughout the whole life of a patient, the insulin with a short duration of action during mealtime throughout a day, as well as the insulin with a long-acting, nonpeak analogue - so-called the basal level (insulin slowly absorbed in the suspension, which is administered once a day). The treatment requires from a patient several subcutaneous injections of the drug in solution and systematic, repeated examination of glucose level in blood. The basic method of the treatment of type 1 diabetes is insulin therapy performed by repeated injections of insulin or by means of continuous subcutaneous infusion with a personal insulin pump (16). This type of diabetes most frequently occur among children and adolescents. It is one of the most common chronic diseases of the age of adolescence. There is a dynamic increase in the incidence of diabetes in the world and in Poland (17).

The typical symptoms of type 1 diabetes are: polydipsia, polyuria, weight loss, drowsiness, fatigue and progressive dehydration. The treatment aims at the best alignment of diabetes, because it is a key element that reduces the risk of developing serious complications (18).

People with type 1 diabetes must regularly monitor the level of blood glucose (glycaemia), follow healthy eating habits with the restriction of simple sugars, and use insulin therapy. This causes a change in a style of their current life, the threat of depressive episodes (especially among adolescents) (19), as well as anxiety symptoms. The occurrence of these disorders may result in impediments in the performance of everyday activities and affect the quality of social functioning (20).

\section{DIAGNOSTIC CRITERIA}

Diagnostic criteria for diabulimia are similar to those adopted by the Diagnostic and Statistical Manual (DSM) for the diagnosis of eating disorders in people without carbohydrate disorders, i.e. anorexia nervosa (AN), bulimia nervosa (BN) or eating disorders defined otherwise (EDNOS, eating disorder not otherwise specified) (21). Diagnosis of this disorder requires a detailed distinction from other eating disorders. It should be also emphasized that in a case of eating disorders occurring in diabetics, these problems are intensified, because in one person two diseases overlap, which lead to catastrophic effects for an organism.

Although these disorders differ in symptoms, they have similar clinical features including psychopathological features and obsession about body shape and body weight are visible next to cognitive distortions such as changes in the body image (22). Quite often, however, 
diabulimics, in addition to reducing insulin doses, also display additional behaviors, typical for anorexia and bulimia, such as: following restrictive diets, even starvation, provoking vomiting, use of laxatives.

\section{Symptoms of diabulimia}

The presence of the following factors should prompt to suspect eating disorders in a patient with diabetes:

- persistent high hemoglobin A1c (glycosylated hemoglobin)

- hyperglycemia

- recurrent episodes of ketoacidosis

- high levels of HbAlc, which can cause irregular menstruation and amenorrhea, and delayed puberty

- unreliable blood glucose monitoring that indicates irregularities in the documentation of glucose measurements

- cancelled or rare control visits of diabetic patients

- low BMI values and low content of fat

- nutritional behaviors similar to people with bulimia nervosa

- excessive concentration on the accurate counting and control of the number of carbohydrate exchangers

- not keeping a self-control diary

- dissatisfaction or lack of acceptance of the own body

- noticeable concentration on the external appearance

- high level of focus on food and related activities

- use of alternative diets (e.g. vegetarianism, veganism, elimination of gluten without medical indications, protein diet)

- very high level of physical activity (23)

"There are also often noticeable changes in the mood and well-being of these patients i.e. lowered mood, depression, apathy, lack of willingness to perform daily activities, fatigue, emotional lability (mood swings), putting too high demands on themselves, excessive scrupulousness and duty, tendencies for strong control "(24).

\section{PHASES OF \\ DEVELOPMENT (25)}

In the source literature there were distinguished three stages of diabulimia development along with accompanying symptoms and health consequences. The first stage (so-called initial) includes symptoms such as headache, weakness, increased drowsiness, high blood glucose, increased thirst and frequent urination. The second stage is intensified by the symptoms occurring in the
HOFFMANN B.

first stage, dehydration of the body, weight loss caused by, among others, atrophy of muscles. At the third stage it comes to kidney damage, sight damage, which can even lead to blindness, retinopathy, nephropathy, ketoacidosis, peripheral neuropathy and autonomic neuropathy. In addition one feels the extreme fatigue.

\section{DIABULIMIC THAT IS WHO?}

Scientific research shows that diabulimia, as well as other eating disorders, affects mostly women (26). This is explained by the fact that women to the greater extent than men attach importance to the external appearance, including a well-proportioned, slim figure. Thus, they try to control body weight by limiting food. This view is indeed confirmed by statistics, but it is increasingly emphasized that this phenomenon also occurs in men (27). However, they strive to reduce body weight not only through poor nutrition, but above all through too intense physical exercise. The researchers point out that the problem of deliberately omitting insulin dosing may concern from 15 to even $40 \%$ of young diabetics, both sexes (28). The problem affects mostly teenagers during their puberty (29), and interesting cases have been described in professional literature (30).

\section{DIABULIMIA PREDISPOSITIONS}

Personality predispositions and socio-cultural factors are determined as the main risk factors of development of eating disorders.

Personality conditions affecting development of diabulimia, similarly to anorexia or Pro-ana behaviors (31), include: negative self-esteem and tendency towards other compulsive behaviors (32), tendency to suppress emotions, low degree of autonomy, perfectionism, low resistance to stress or so-called external location of the sense of control (33). The socio-cultural conditions include, above all, family factors and social factors inherent in the wider environment of an individual, as well as in the culture in which his/ her life runs. Strong subordination to the family system, parents' overprotection, vaguely defined boundaries in relations among family members and the role of a child in the family system, denial of conflicts and difficulties in solving them, stiff behavior, fear of change, involving a child into the conflict between parents and entering in coalition with one of them (34), all these heighten the danger of falling into the diabulimia. 
HOFFMANN B.

The factors triggering the occurrence of the disease include critical remarks about appearance and fatness, coming from the nearest environment, weight loss trends popular among peers, as well as family behavior, reinforcing abnormal food-related behaviors. Here I mean these factors that create dependencies in the family based on the feedback model. As Jolanta Rogala Obłękowska emphasizes, "one of the most important concepts describing the dynamics of a family is the concept of the feedback loop, transferred to social sciences from cybernetics, which means replacing the linear cause and effect dependency by the circular dependency. What does it mean? Family members influence on each other, but these interactions are not linear in nature, i.e. the cause and effect cannot be clearly distinguished, because in a complicated system of family relationships what seems to be the cause - may be the result of previous interactions "(35). These factors include: focusing on a patient's illness, reducing or abandoning family and marital conflicts related to a child's illness, as well as all these family behaviors that aim to "hold" the family together. Of course, the opposite situations may happen, where the illness of a family member, here a young person suffering not only from diabetes, but also diabulimia, triggers the effect of the family's disintegration. Polivy and Herman, as well as Latzer together with the research team, pay attention to the importance of a family in the sense of the self-esteem in adolescents and existence of factors so much predisposing to development of bulimia as: humiliation, excessive criticism by parents, lack of emotional support, disturbed communication in a family ( 36), limiting the autonomy of an individual and too high degree of controlling (37).

At this point I would like to pay a special attention to socio-environmental factors related to the culture of the "skinny body", in which the appearance itself constitutes a determinant of a life success, brings recognition and admiration.

A human body determined by biology is at the same time influenced by culture. In contemporary societies, the transfer of knowledge about canons of beauty and ways of caring for it is a significant element of socialization in both children and teenagers (38).
For centuries, a family was the most important, even the only area of activities undertaken by a woman, defining her relationship with other people and social groups, deciding about her social position, as well as defining her identity and constituting the criterion for her evaluation. That was a family that shaped a woman, influenced her behaviors, aspirations and ways of perceiving the world. Social and family roles were strictly defined, imposed in advance and constituted the dominant component of a human personality (39).

Consumer culture began to control the forms of "existence" (40), making a body the supreme organ of consumption. In times of strong competition, both in the professional and personal fields, there is a constant compulsion to create the most desirable social image. Thus, the features associated with beauty and vitality grow into obsessively desirable ones. The body gained not only aesthetic, but above all economic value, while the slim figure became a normative category (41). This 'culture of thinness' exerts enormous pressure, leading to a pathological concentration on diets. The requirements imposed on the modern body apply to a greater extent to women than men.

According to surveys conducted in Poland by CBOS, almost all Poles believe that an attractive image and attention to their appearance determines success in personal (90\%) and professional (92\%) life. The same studies show that their own appearance is important for almost all respondents, although it loses importance as the age of respondents increases, but even among respondents over $65,80 \%$ declare that their own appearance is of great importance to them, and in the range of 18-24 years, this percentage is $96 \%$ (42). Similar results may also be found in other countries.

Simultaneously, more and more girls and women are dissatisfied with their appearance (43). The conviction that the external appearance depends largely on ourselves and regardless the genetic heritage or inherited features, we can freely change it, making it similar to the current canon, has become the product of our times. The ideal, however is most often unattainable and the undertaken path is endless, because one cannot achieve a satisfactory level of perfection. It seems that this belief entails many negative effects, including the already mentioned eating disorders. 
HOFFMANN B.

An important role in the perception of our body is played by mass media. Starting from the presentation of all "wonderful diets", exercises, preparations and cosmetics, through citing the stories of people who lost a lot of kilograms (often with "before" and "after" photos) to articles and programs about the benefits of plastic surgery, performing "miracles" "(for an adequate amount of money matching everyone to the obligatory "form") (44). In the face of an abundance of messages of this type, a slim, well-groomed body becomes a normative requirement with a ready recipe for its fulfillment.

It is media that promote specific habits, patterns and models to follow. The almost unlimited technical possibilities of television or other visual media make that the presented image appears to mostly young people as very attractive, worth imitating and above all, possible to implement. Without the criticism that characterizes a mature recipient, a teenager eager for an ideal to imitate, may uncritically accept transmitted content regarding appearance or lifestyle. Media, using this situation, create a kind of the mass culture aimed at young people. By focusing on their needs, interests and preferences, and making the self-esteem from the very fact of "being" young and having typical for youth physical and psychological traits, the media shapes the identity of a young generation. Popular lyrics and heroes are the source of creating a sense of community and youthful cultural practices, including those regarding their appearance and health (45).

The thinness, assuming the control over eating, has become the synonymous of strong will, perfectionism, success and attractiveness (46), success in peer and wider communities. Such understanding of corporality also contains a significant contradiction. On the one hand there is the cult of a body, its affirmation in the aforementioned mass media (photos, articles, programs referring to corporeality or simply "using" a body), on the other hand, a body is constantly kept in check, disciplined by diet or gymnastics. Despite warnings against eating disorders that appear in women's magazines, important places are still taken by advice on how to slim down and fight with someone's own figure.

The boundary between taking care of a body for a better wellbeing, maintaining health and physical fitness and the moment when your own appearance becomes the most important issue in the life and the only form of selfdetermination, has been crossed in a dangerous way. Millions of girls, but also adult women around the world, although they are not diagnosed by doctors as suffering from one of the diseases associated with eating disorders, devote a significant part of their time, attention and life energy to "discipline their body", based on this self-esteem values (47) Just as the boundary between the natural body and the artificially created is blurred, the line separating the lifestyle from the disease is also blurred (48).

\section{THE SCALE OF DIABULIMIA}

Eating disorders may affect about $20 \%$ of women with type 1 diabetes (49). There are recent reports showing that up to $30 \%$ of girls with diabetes in their youthful age suffer from eating disorders (50). In the observation study conducted by Colton and his co-workers, it was shown that $32.4 \%$ of young patients with type 1 diabetes met the criteria of eating disorders while $8.5 \%$ of the examined reported eating disorders of nonspecific character. In addition, it was noted that in $60 \%$ of patients, the disease started before the age of 25 . In the study group, the mean time between the onset of the disease and the occurrence of remission was 4.3 years. The mean length of remission before the recurrence of the disease is 6.5 years (51).

\section{THE EFFECTS OF DIABULIMIA}

Diabulimia, like other eating disorders, causes serious health effects, which are discussed in detail in the medical literature. At this point, I just want to point out that in the case of eating disorders occurring in people with type 1 diabetes, problems are intensified, because one person has two diseases that lead to effects which destroy a body. Intentional skipping of insulin doses can lead not only to the loss of body weight, which becomes the target of a patient, but also to very serious health effects, to coma and even death of a patient.

\section{SORTS OF HELP}

Diabulimia has not been formally recognized as a disease entity and therefore there are no clear diagnostic criteria for its detection. The proper preparation of medical personnel is crucial here, both in terms of detecting the disorder and its treatment. The basis is to identify as soon as possible both, alarm signals of diabulimia and risk factors that lead to its development. 
Strategies of diabulimia treatment are the same as in the treatment of eating disorders, in the whole population. Among the applied forms of therapy there are mentioned: psychotherapy, pharmacological treatment and hospitalization. Psychotherapy (primarily CBT, DBT) (52) in diabulimia most often takes on the form of individual, group or family therapy (53). The results of the research indicate a greater effectiveness of a family therapy in comparison with an individual therapy, especially when the problem affects a child (54).

In justified cases, the psychotherapeutic interaction is combined with the pharmacotherapy. In some cases, outpatient treatment may not be sufficient and hospitalization in a specialized center is necessary.

The essential element of an effective treatment is the interdisciplinary nature of the therapeutic team. A close cooperation is needed between a psychotherapist and a psychiatrist with a diabetes doctor, nurse, diabetes educator and dietitian. Only in this way can the patient be allowed to improve the metabolic control of diabetes, monitor the progress of the therapy, and control the changing insulin requirement during the change of a patient's body weight and her/ his eating behavior. Together with the change in a body weight of a sick person, there is also a change in needs for the daily energy (55).

\section{CONCLUSION}

Although diabulimia is not a separate medical term and is considered as a subcategory of anorexia or bulimia, it is distinguished from these disorders by a specific situation of a sick person: coexistence of another disease insulin-dependent diabetes mellitus. For this reason, this disorder requires a special approach and cooperation of specialists of various specialties.

The same as in the case of other addictions, also here prophylaxis seems to be important. To reduce the spread of the disease, actions are required at many different levels, e.g. information campaigns among children and adolescents, as well as among medical staff (56). Certainly, it is necessary to educate and sensitize physicians, including primary care physicians, to the existing problem, changing eating habits and their often dramatic effects. No less important are the observations of families, relatives and all those in the vicinity of which a diabetic lives, as well as their involvement in the subsequent process of treatment.

Finally, it's worth noting that not all people who limit insulin, do it to lose weight. Some diabetics have psychological barriers to their condition, including cognitive problems, anxiety associated with injections (needle phobia), mood disorder, social barriers and fear of hypoglycemia (57).

It is certainly necessary to further study the phenomenon and work on the popularization of the knowledge about this problem in the widest possible environment.

\section{REFERENCES}

1. Jośko J., Kamecka-Krupa J., Czynniki ryzyka anoreksji [Anorexia risk factors]. Problemy Higieny i Epidemiologii, 88(3), p. 254-258, 2007.

2. Żechowski C. , Historia badań nad jadłowstrętem psychicznym [The history of research on anorexia nervosa]. Postepy Psychiatrii i Neurologii, 13(3), p. 247-253, 2004.

3. Ibid.

4. Vandereycken, W., \& Van Deth, R., From fasting saints to anorexic girls: The history of self starvation, NY: University Press, New York, 1994.

5. Habermas, T., The role of psychiatric and medical traditions in the discovery and description of anorexia nervosa in France, Germany, and Italy 1873 - 1918. Journal of Nervous and Mental Disease, 179, p. 360365, 1991.

6. Escamilla R. F., Lisser H., Simmonds' Disease. A Clinical Study with Review of the Literature; Differentiation from Anorexia Nervosa by Statistical Analysis of 595 Cases, 101 of Which Were Proved Pathologically. The Journal of Clinical Endocrinology\&Metabolizm, Published Online: July 2013. http://press.endocrine.org/doi/abs/10.1210/j cem-2-2-65

7. Józefik B., (ed.), Anoreksja i bulimia psychiczna. Rozumienie i leczenie zaburzeń odżywiania się [Anorexia and bulimia nervosa. Understanding and treatment of eating disorders]. Wydawnictwo Uniwersytetu Jagiellońskiego, Kraków, 1999.

8. Russell G., Bulimia nervosa: an ominous variant of anorexia nervosa. Psychological Medicine, 9(3), p. 429-448, 1979. 
9. Bratman S., Health Food Junkie. Yoga Journal, October, p. 42-50, 1997. http://books.google.pl/books?id=AOoDAA AAMBAJ\&printsec $=$ frontcover $\& \mathrm{hl}=\mathrm{pl} \&$ so urce $=$ gbs_ge_summary_r\&cad $=0 \# v=$ onepa ge \&q\&f=false

10.Ruth-Sahd L. A., Schneider M., Haagen B., Diabulimia What it is and how to recognize it in critical care. Dimens. Crit. Care. Nurs., vol. 28, 4, p.147-153, 2009.

11.Callum A. M., Lewis L. M., Diabulimia among adolescents and young adults with Type 1 diabetes. Clinical Nursing Studies, vol. 2, No. 4, p.12-16, 2014.

12.Ibid.

13.https://www.nationaleatingdisorders.org/dia bulimia, (accessed on 14.06.2018)

14.https://diabetyk24.pl/blogsection/przecukrzenie-sposobem-naodchudzanie, (accessed on 22.06.2018)

15. Wojtczak A. (red.), Choroby wewnętrzne [Internal diseases]. Wydawnictwo Lekarskie PZWL, Warszawa 1995.

16.Szadkowska A, Bodalski J., Insulinoterapia u dzieci i młodzieży chorej na cukrzycę typu 1 [Insulin therapy at children and adolescents with type 1 diabetes], Przegl. Pediatr. 34 (3-4), p. 161-169, 2004, after: Hacia S., Cichoń L., Nowak M., Fuchs A., Jarosz-Chobot P., Janas-Kozik M., Zachowania autoagresywne u pacjentek chorujących na cukrzycę typu 1 leczonych na oddziale klinicznym psychiatrii i psychoterapii wieku rozwojowego - opis przypadków [Autoaggressive behavior in patients with type 1 diabetes treated in the clinical division of psychiatry and psychotherapy in the age of puberty report of cases]. Psychiatr. Pol. 47(5), p. 887-896, 2013.

17.Hacia S., Cichoń L., Nowak M., Fuchs A., Jarosz-Chobot P., Janas-Kozik M., op. cit.

18.Ibid.

19.Duda-Sobczak A, Wierusz-Wysocka B., Cukrzyca a choroby psychiczne [Diabetes and mental illness]. Psychiatr. Pol. 45 (4), p. 589-598, 2011; Szymańska S., Występowanie objawów depresyjnych u młodych diabetyków i ich związek $z$ efektywnością leczenia cukrzycy [Occurrence of depressive symptoms in young diabetics and their relation to the effectiveness of diabetes treatment]. Psychiatr. Psychol. Klin., 7 (4), p. 219-226, 2007, after: Hacia S., Cichoń L., Nowak M., Fuchs A., Jarosz-Chobot P., JanasKozik M., op. cit.
HOFFMANN B.

20.Hacia S., Cichoń L., Nowak M., Fuchs A., Jarosz-Chobot P., Janas-Kozik M., op. cit.

21.American Psychiatric Association: Diagnostic and Statistical Manual of Mental Disorders, Fifth Edition, Arlington, VA, American Psychiatric Association, 2013

22.Callum A. M., Lewis L. M., op. cit.

23.Callum A. M., Lewis L. M., op. cit., Juruć A, Kubiak M, Wierusz-Wysocka B., op. cit.

24.Juruć A, Kubiak M, Wierusz-Wysocka B., op. cit.

25.Polansky W. H., Anderson B. J., Lohrer P. A., Aponte J. E., Jacobson A. M., Cole C. F., Insulin omission in women with IDDM. Diabetes Care, vol. 17, p. 1178-1185, 1994;

26.Ruth-Sahd L. A., Schneider M., Haagen B. Diabulimia What it is and how to recognize it in critical care. Dimens. Crit. Care. Nurs. vol. 28, 4, p. 147-153, 2009.

27.Callum A. M., Lewis L. M., op. cit.

28.Neumark-Sztainer D., Patterson J., Mellin A., Ackard D.M., Weight control practices and disordered eating behaviours among adolescent females and males with type 1 diabetes: association with sociodemographics, weight concerns. Diabetes Care; vol. 25: 1289-1296, 2002, after: Juruć A, Kubiak M, Wierusz-Wysocka B., op. cit.

29. Meltzer L. J., Johanson S. B., Prine J. M., Disordered Eating, Body Mass and Glycemic Control in Adolescents with Type 1 Diabetes. Diabetes Care, vol. 26, p. 678682, 2001.

30.Jaffa T, McDermott B. Eating Disorders in Children and Adolescents. Cambridge University Press, p. 177-178, 2006.

31.Kınık M. F., Volkan Gönüllü F., Vatansever Z., Karakaya I., Diabulimia, a Type I diabetes mellitus-specific eating disorder. Turk Pediatri Ars, 52, p. 46-9, 2017. Turkish Pediatric Association Available online at www.turkpediatriarsivi.com DOI: 10.5152/TurkPediatriArs.2017.2366

32.Hoffmann B., Pro ana (1): eating disorder or a lifestyle?. Trakia Journal of Sciences, No 2, p. 106-113, 2018.

33. Woronowicz B. T., Uzależnienia. Geneza, terapia, powrót do zdrowia [Addictions. Genesis, therapy, recovery]. Media Rodzina i Parpamedia, Warszawa, 2009.

34.Hoffmann B., op. cit.

35.Rogala - Obłękowska J., Narkoman w rodzinie. Wskazania do terapii [A drug addict in the family. Indications for therapy]. Uniwersytet Warszawski, Instytut 
Stosowanych Nauk Spolecznych, Warszawa 2002.

36.Rogala - Obłękowska J., op. cit.

37.Okon D.M., Greene A.L. , Smith J.E., Family interactions predict intraindividual symptom variation for adolescents with bulimia. International Journal of Eating Disorders, vol 34, issue 4, p. 450-457, 2003.

38.Bonne O., Lahat S., Kfir R., Berry E.M., Katz M., Bachar E., Parent-Daughter Discrepancies in Perception of Family Function in Bulimia Nervosa. Psychiatry: Interpersonal and Biological Processes: vol. 66, No. 3, p. 244-254, 2003.

39.Łaciak B., Socjalizacja do troski o urodę [Socialization to care for beauty], in: M.S. Szczepański M.S., Pawlica B., Śliz, A., Zarębska-Mazan, A. (ed.). Ciało spieniężone? Szkice antropologiczne i socjologiczne [En-cashed body? Anthropological and sociological sketches]. Śląskie Wydawnictwa Naukowe. Tychy Opole, 2008.

40.Garncarek E., Kobiece ciało jako przedmiot kontroli społecznej [Female body as a subject of social control]. Przeglad Socjologiczny, vol. 59 (3), p. 55-69, 2010.

41.Jakubowska H., Socjologia ciała [Sociology of a body], Wydawnictwo Naukowe UAM, Poznań, 2009.

42.Pilecki M. W., Józefik B., Sałapa K., op. cit.

43. Attitude to someone's own body - the ideal of a beautiful woman and a handsome man. CBOS Announcement. Developed by K. Biały, Warszawa, 2003.

44.L. Papadopoulos, Lustereczko powiedz przecie... Rewolucja w myśleniu o własnym wyglądzie [ Mirror, mirror on the wall ...Revolution in thinking about someone's own appearance]. Kraków, 2005.

45. Owsiejczyk A. op. cit.

46.Ibid.

47.Pilecki M. W., Józefik B., Sałapa K., Kontekst kulturowy zaburzeń odżywiania się - badania własne [Cultural context of eating disorders - own research]. Psychiatria Polska, vol. XLVI, nr 2, p. 189-200, 2012.

48.Owsiejczyk A. op. cit.

49. Hoffmann B., op. cit.

50.Markowitz J., Butler D.A. Volkening, L.K., Antisdel J.E, Anderson B.J, Laffel L.M., Brief screening tool for disordered eating in diabetes: Internal consistency and external validity in a contemporary sample of paediatric patients with type 1 diabetes. Diabetes Care, 33, p. 495-500, 2010, after: Juruć A, Kubiak M, Wierusz-Wysocka B., op. cit.

51.Jones J.M., Lawson M.L., Daneman D., Olmsted M.P., Rodin G., Eating disorders in adolescent females with and without type 1 diabetes: cross sectional study. British Medical Journal, 10, 320, p. 1563-1566, 2000, after: Juruć A, Kubiak M, WieruszWysocka B., op. cit.

52.Colton P.A., Olmsted M.P., Daneman D. and coworkers, Eating Disorders in Girls and Women With Type 1 Diabetes: A Longitudinal Study of Prevalence, Onset, Remission, and Recurrence. Diabetes Care, 38, p. 1212-1217, 2015, after: Juruć A, Kubiak M, Wierusz-Wysocka B., op. cit.

53.Anderson D. A, Maloney K.C., The efficacy of cognitive-behavioral therapy on the core symptoms of bulimia nervosa. Clin Psychol Rev., 21(7), p. 971-988, 2001. http://dx.doi.org/10.1016/S02727358(00)00076-3;

54.Latner J. D., Wilson G. T., Cognitivebehavioral therapy and nutritional counseling in the treatment of bulimia nervosa and binge eating. Eat Behav., 1(1), p. 3-21, 2000. http://dx.doi.org/10.1016/S14710153(00)00008-8;

55.Goebel-Fabbri A.E., Fikkan J., Franko D.L., Pearson K., Anderson B.J., Weinger K., Insulin restriction and associated morbidity and mortality in women with type 1 diabetes, Diabetes Care, 31, p. 415419, 2008, after: Juruć A, Kubiak M, Wierusz-Wysocka B., op. cit.

56.Juruć A, Kubiak M, Wierusz-Wysocka B., op. cit.

57.Ibid.

58.Bator E., Bronkowska M., Ślepecki D., Biernat J., Anoreksja - przyczyny, przebieg, leczenie [Anorexia - causes, course, treatment], Nowiny Lekarskie, 80, 3, p. 184-191, 2011.

59.Logan -Stotland N. , Overcoming psychological barriers in insulin therapy. Insulin, 1(1), 2006, 38-45. http://dx.doi.org/10.1016/S15570843(06)80006-0, after: Callum A.M., Lewis L.M., op. cit. 